Jan Paweł II. Posługa myślenia, t. 2, red. ks. B. Kastelik, A. Krupka, ks. R. Woźniak, Kraków 2015, s. 163-191

(Studia nad Myślą Jana Pawła II, 17).

DOI: http://dx.doi.org/10.15633/9788374384933.10

Matt Libra

\title{
JEAN-PAUL SARTRE AND JOHN PAUL II: FREEDOM, THE LOOK, AND SHAME
}

What makes a person a person? Is there a certain way we ought to treat others because they are human beings? The value of personhood affects how people treat other people in daily interactions, civil rights, human dignity, and even moral obligation. Two contributors to the discussion of personhood are the French philosopher, Jean-Paul Sartre and the Roman Catholic Pope, John Paul II. Interestingly, both men use similar terms in trying to describe the person, yet they begin from opposite starting points and come to differing conclusions. John Paul II argues that people ought always to treat others as an end in themselves, based on their personhood, while Jean-Paul Sartre posits that to be a person is to be free, even if that leads to treating another person as a means. John Paul II describes how mankind ought to be, Jean-Paul Sartre describes the person as he observes them, one who disregards the dignity of the other, who John Paul II calls "the man of concupiscence."

In order to better understand human dignity and the "man of concupiscence," we will examine the common elements between John Paul and Jean-Paul, viz. objectivity versus subjectivity, freedom, "the look," and shame. Before diving into their ideas, a brief history of these two men will allow us to see where they are coming from.

\section{Jean-Paul and John Paul}

Jean-Paul Sartre was a peculiar, five foot three inch man with a lazy eye, who was quite popular in his day. As a respected intellectual critic and writer, 
he was offered the Nobel Prize for literature in 1964. He turned down the prize, revealing his thirst for intellectual integrity and distaste for popular acclaim. He was born on June 21, 1905 in Alsace-Lorraine France. His father died when Sartre was only a year old, so his mother moved back to her parents' house where young Sartre was raised with help from his grandparents. His mother remarried when Sartre was twelve years old, and shortly afterwards he began to deny the existence of God, contrary to the belief of his grandfather and stepfather. ${ }^{1}$ When he was seventeen, he attended the Sorbonne to study philosophy. There he met Simone de Beauvoir, who became a lifelong friend and lover, though the two would never marry.

During his life, Sartre was involved with all things literary, from writing plays and novels, to political essays and books on philosophy. He taught, edited a journal, was drafted into World War II in 1939, and was even a prisoner of war for a year in a German camp. ${ }^{2}$ In prison, Sartre began to write Being and Nothingness, which he published two years after his escape from prison in $1941 .{ }^{3}$ At times, Sartre's philosophy made him popular. At other times he was forced to flee from the French army and bomb attacks for his outspoken political views. ${ }^{4}$ Sartre was friends with Albert Camus and Pablo Picasso, and for a time he even "converted" to Marxism. ${ }^{5}$ Perhaps because of friendships like these, he wrote on many different topics throughout his life, despite the harassment or success he incurred. Overall, Sartre left a lasting impact on the public of France because of his existential theory. His popularity was demonstrated by the 50,000 people who attended his funeral on April 15, 1980. ${ }^{6}$ No doubt the many experiences he had led to what he wrote, and what he wrote would have a ripple effect on the moral thought of society.

Near the end of Sartre's life, John Paul II stepped onto the world scene. John Paul II became Pope in October of 1978 and led the Roman Catholic Church until his death on April 2, 2005. Fifteen years Sartre's junior, he was born in Poland and named Karol Wojtyła at his birth on the eighteenth of May 1920. Karol had an older sister who did not live to the time of his birth. His mother died when he was nine years old, followed by his brother when

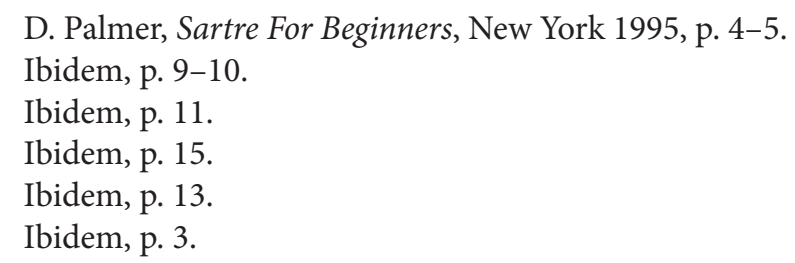


he was twelve. By the time he was twenty-one his father passed away. ${ }^{7}$ This harsh start in life did not stifle Karol; rather, he applied himself to various activities. He loved spending time outdoors hiking, skiing, or canoeing with friends, and also took an interest in literature and theatre.

During World War II, Karol Wojtyła heard the call to priesthood and entered the seminary while continuing to work in a rock quarry so as to keep his training hidden from Nazi notice. He was ordained to the priesthood in 1946 and eventually became the bishop of Krakow, Poland in $1964 .{ }^{8}$ During these years he continued to study, notably in the areas of theology and phenomenological philosophy. Just three years after he was ordained a bishop he was created cardinal. In this position he participated in each of the synods of Vatican II, himself making significant contributions to the conciliar documents. ${ }^{9}$ When he became Pope he took the name John Paul II, the name and title by which most people are familiar with him.

As Pope he was involved with peoples and nations from all over the world. Not only did he visit various Churches throughout the world, but he also met personally with leaders from many, if not most, nations in the world. He had nearly 1,000 meetings with national leaders from around the world, as well as celebrating nineteen world youth day gatherings, beatifying 1,338 people, and canonizing 482 Saints. ${ }^{10}$ In addition to all this activity, he authored fourteen Encyclicals, fifteen Apostolic Exhortations, eleven Apostolic Constitutions, and forty-five Apostolic Letters; in his free time he also wrote five books. ${ }^{11}$ John Paul II sought to address the true needs of people all over the world. In fact, his work in the Solidarity Worker Movement in Poland had a significant impact on the fall of communism. In the March 3, 1992 edition of $L a$ Stampa, Gorbachev himself announced that the fall of communism "would not have been possible without the presence of this Pope, without the great role even political that he has played on the world scene." John Paul's love for all humanity led him to write extensively on sexuality and the value of the human person. After his death, over three million people came to honor his remains, testifying to the impact of his life on the world.

\footnotetext{
Holy See Press Office, Biography of John Paul II, in http://www.vatican.va/news_ser vices/press/documentazione/documents/santopadre_biografie/giovanni_paolo_ii_biogra fia_breve_en.html (30 June 2005).

Ibidem.

Ibidem.

Ibidem.

11 Ibidem.
} 
Both Jean-Paul and John Paul left a lasting impact on the world around them. One can also say that both acted in response to what they believed. Fortunately for us, they also wrote about what they believed in regards to the human person. As we examine their works we will see that John Paul II articulates that man ought to be treated as an end in himself. He asserts that man is often treated as a means to some other end due to concupiscence, which is a distortion of man's true nature. At the same time, we will see that Jean-Paul Sartre offers an account of man that corresponds to John Paul's man of concupiscence.

\section{Objectivity versus subjectivity}

To the humble man, and to the humble man alone, the sun is really a sun; to the humble man, and to the humble man alone, the sea is really a sea.

\section{G. K. Chesterton in Heretics}

In order to answer the question "what is a person?" we will need to discuss objectivity and subjectivity. Right away we come to a problem of confusing, or at least easily misunderstood, vocabulary. After briefly defining these terms we will examine them each more carefully. The words "object" and "subject" can have different meanings depending on the context in which they are used. Before John Paul II became Pope, he wrote a book entitled Love and Responsibility. He wrote that "every subject also exists as an object, an objective 'something' or 'somebody". 12 "Objectivity" indicates a particular thing (object) that exists in the world, while "subjectivity" indicates knowledge of one's own self. ${ }^{13}$ All subjects appear as objects, but not all objects are subjects.

An "object" is made known to the world by its physical existence. In this sense a person is an object, as one existing in the physical world. Imagine a person, Wendy, employing her sense of sight. She sees three things, a chair, a dog, and her friend Jack; all three appear to her as objects (objects of her consciousness). In this sense it is proper to refer to all three as objects. However, although Jack appears to Wendy as an object, he is in fact an objective somebody, he is also a subject.

\footnotetext{
12 K. Wojtyła, Love and Responsibility, San Francisco 1993, p. 21.

13 John Paul II, The Theology of the Body, Boston 1997, p. 37.
} 
To be a "subject," in the sense that we are using it here, an object must have the capacity for self-knowledge. The ability to reason "differentiates a person from the whole world of objective entities, this determines the distinctive character of a person". ${ }^{14}$ Beyond the fact that Jack is an object of Wendy's sight, he is also a subject because he has the capacity for self-knowledge. Using his reason, the person can reflect on themselves and differentiate themselves as an object separate from other objects. In this way, Jack can recognize himself as a subject in the objective world. A person then is a subject because he is imbued with rational powers and has the capacity for self-knowledge. All beings who share this rational power and capacity for self-knowledge are properly identified as subjects existing in a world of objects.

Distinguishing the terms "objectivity" and "subjectivity" from "objective" and "subjective," will lessen confusion of terms. "Objective" can also be used to mean impartial, while "subjective" can be used to mean biased. Objectively, all persons could and would come to the same conclusion; this object is a man, that object is a ball, another object is a White-eared Marmoset found primarily in the Atlantic costal forest of Brazil. We can impartially posit that many objects exist in the world, which is the fact of the matter. Subjectively speaking the object could appear differently to various people depending on the circumstances, such as the angle which you look at the object, how long you look at it, how interested you are in it, and so forth. It is important to recognize that each person, as a subject, has a biased/subjective view of the objects they behold; however, this does not mean that there is no true/objective reality. It is important to make distinctions "between what is objectively right and wrong, and what is subjectively liked or disliked. For, if the emotions rule, one may erroneously equate what one likes, with what is true, and what one dislikes, with what is false". ${ }^{15}$

Sartre uses these same nuanced terms, but his starting point and conclusion are different. As an existentialist he holds that "existence comes before essence - or, if you will, that we must begin from the subjective". ${ }^{16}$ He uses "subjectivity" similarly to John Paul II. "Subjectivism means, on the one hand, the freedom of the individual subject and, on the other, that man cannot pass

\footnotetext{
$14 \quad$ K. Wojtyła, Love and Responsibility, cit., p. 22.

15 P. Harding, Homily on Luke 6:27-38, St. Benedict, OR 2007.

16 J. P. Sartre, Existentialism and Humanism, [in:] The Study of Human Nature, New
} York 2002, p. 186. 
beyond human subjectivity". ${ }^{17}$ Here Sartre states that all men are individual subjects, while at the same time sharing a common humanity. The person is a subject that shares in freedom with all other human persons. He further asserts that what is true of humanity cannot be different from person to person. Another way of putting it is that the person's subjectivity determines what the person is objectively. For example, because Jack is a person, Wendy recognizes him as actually existing as a person.

Instead of recognizing the existing person as a subject in a world of objects, as John Paul II does, Sartre starts with the person as a subject and throws him into the world of objects to fend for himself. This creates some confusion for defining just exactly what it means for a person to be a subject. To define what a subject is Sartre delves into the philosophical world of phenomenology. Phenomenology is a method of understanding the world by being conscious of objects presented to us in the world.

In his work Being and Nothingness, Sartre explains that the person is an ontological duality of "being in-itself" and being "for-itself". ${ }^{18}$ Simply put, in the human person being in-itself may be likened to the objective matter of which the being is composed, while being for-itself may be likened to the consciousness, in which subjectivity lies. For Sartre, the person is a unity of the for-itself and the in-itself.

Being in-itself "simply is". ${ }^{19}$ As an existentialist, Sartre asserts that "man first of all exists, encounters himself, surges up in the world - and defines himself afterwards. If man as the existentialist sees him is not definable, it is because to begin with he is nothing". ${ }^{20}$ The person exists as an object, being in-itself. The in-itself provides the objective existence of the real being. As expressed in the person, the in-itself is the body of the person, its physicality, its existence, but it is not the person. The person finds himself in the unity of the in-itself with the for-itself.

The unity implied in the presence of the for-itself can only be "negatively clarified". ${ }^{21}$ Sartre defines the for-itself as "a real lack of being which, qua lack, is beyond being". ${ }^{22}$ The for-itself as consciousness, is consciousness of some

\footnotetext{
17 Ibidem, p. 188.

18 C. Macann, Four Phenomenological Philosophers, New York 1993, p. 125.

19 R. Cumming, The Philosophy of Jean-Paul Sartre, New York 1965, p. 179.

20 J. P. Sartre, Existentialism and Humanism, cit., p. 186.

21 C. Macann, Four Phenomenological Philosophers, cit., p. 126.

22 R. Cumming, The Philosophy of Jean-Paul Sartre, cit., p. 178.
} 
thing. As a unity with the in-itself, the for-itself has consciousness of the in-itself. It recognizes that it is not the in-itself, but it also recognizes a lack in the in-itself. Becoming conscious of itself, the for-itself recognizes itself as the lack in the in-itself. "It is insofar as there is in it something of which it is not the foundation - its presence to the world" ${ }^{23}$ The for-itself recognizes itself as nothing in its union with the in-itself, which in turn reveals the for-itself to the world.

An analogy may be helpful to illustrate these confusing thoughts. The human body is made up of matter: blood vessels and bones, skin and hair, organs and nerves. You might see a person and say, "his arm is broken," or "her hair is blond." In response your friend can go and look and see a man's arm and recognize it as broken, or to a woman's hair and see that it is blond. This corresponds to the in-itself, the physical matter that you can touch, dissect, and look at.

The for-itself is not recognizable like that. Take emotion for example. You might see the man with a broken arm and say, "he is sad," or the woman with blond hair and comment, "she looks happy." After hearing your comments, your friend may go to look at the man but not find sadness anywhere, or to the woman and not find happiness in her. Your friend may dissect a thousand corpses, but never find where "emotion" lies. That is because emotion is not a certain part of the body; it is a kind of awareness of what is happening in the body. It is somehow separate or different from the matter of the body, while at the same time expressed through the body. We recognize emotion as its own "entity" even though we cannot find it in the body. In the same way the for-itself expresses itself by means of the in-itself, but it is not the in-itself.

Sartre then defines the person as an ontological unity (an expression of one being) of the for-itself and the in-itself. In so doing, he has also defined the person in terms of objectivity and subjectivity. According to his definition, the subjective for-itself exists and presents itself to the world through the objective in-itself. So then Sartre's definition of the person is a subjective existence through an objective presence.

\subsection{Meet Wendy and Jack...}

Wendy and Jack are two twenty-somethings, who like each other, live together, are sexually active, and are not yet married. Let us also assume for our example that they have genuine feelings for one another. Jack and Wendy are

$23 \quad$ Ibidem, p. 167. 
both persons. They have minds; they can reason and have the ability to look back on their lives and reflect on what they have done. Both Sartre and John Paul II agree that they objectively reveal themselves to one another through their bodies. But the body (Sartre's in-itself) does not define who the person is. The person is a subject (Sartre's for-itself).

Jack, for his part, is happy with his life. He grew up a typical guy. In high school he got decent grades and played sports. He got a job in a retail store when he was in high school and has worked hard to get a promotion to a management position. There are some things he did that he is not too proud of, things he does not necessarily want the whole world to know. He has had a few sexual partners, "just like everyone else". With each sexual partner he felt a little disaffected. To be sure, he enjoyed the experiences and the sexual stimulation was pleasing, but he could not help from feeling like he was missing something, as if there should be something more. In his own words, "having sex is like taking a helicopter to the top of Mt. Everest. The view sure is good, but when you look at the guys who actually climbed their way up, you can see something is different in the way they look at the view because of their accomplishment. When you go home, you just check one more thing off your list without feeling like you have really been changed or satisfied. The guys that climbed seem changed somehow, more satisfied."

Jack does not tell people about the time he got suspended for streaking across the football field naked, his visits to porn sites when he surfs the net, the disconnected relationships he has with his family, and what he has done when he has gotten drunk. He thinks about what he did as he grows older and admits that sometimes he may have gone a little too far when he was having fun, but at least he had a good time along the way. "These experiences make me who I am today," he says, "at least I was being myself and not trying to pretend to be someone I'm not." Jack recognizes that his experiences are different from others and this reflects his "subjective" reality. For the most part Jack is honest with himself, and just wants to be fulfilled and happy. That's when he met Wendy.

Wendy had just graduated from college when she met Jack. She had gone through some rough times in college and was also looking for something to make her happy. Ever since she was little, Wendy has been a sweet girl. She is always considerate of others and tries to do what she can to help. She volunteered to help in the special education classroom at the elementary school while she was in high school; she was not too concerned about being popular, 
but she hoped that people liked her. When she was a sophomore she started dating Billy. Billy made her feel like the happiest girl in the world. He always took her to new places, to parties with his friends, and she liked it when they would just go to his house and she could watch a movie held tightly in his arms. When they were seniors she was sure they were going to get married and they started having sex regularly after her senior prom. They went to college together, and late in her freshman year she thought she was pregnant. She told Billy, but he did not receive the news with joy. He got scared and broke up with Wendy. As it turned out she had a miscarriage in her second month and felt very awkward. Although only Billy knew she was pregnant and she was glad not to have to explain herself to her family, she struggled at both wanting and not wanting the baby she miscarried and that Billy had abandoned her. She just wanted to be happy, but now she felt alone.

On some level Wendy recognized that somewhere along the line, Billy accepted her for her body (objectivity/in-itself) rather than her personhood (subjectivity/for-itself). Her body, or what she could do for him, became more important than who she is: a person who is a self-reflective subject, and therefore possessing an inherent dignity. Three years later she got her teaching degree and began to teach third and fourth grade. She met Jack through a mutual friend and they really hit it off. Jack and Wendy dated for about six months and then decided to move in together. Now they have been living together for close to two years, and things seem to be going pretty well. We will pick up with Jack and Wendy later. For now we need only to recognize how objectivity and subjectivity play out in their relationship according to both John Paul II and Jean-Paul Sartre. Jack's and Wendy's subjectivity marks them with a dignity higher than that of objects. This means that they ought to be treated differently than mere objects. Now we need to examine the proper way to respond to the human subject. To do this we turn to the topic of freedom.

\section{Freedom}

To have a right to do a thing is not at all the same as to be right in doing it.

G. K. Chesterton in A Short History of England

Freedom is foundational in Sartre's concept of the existence of the person. A person's value, or human dignity, is placed on the freedom of being a self 
that is for-itself. ${ }^{24}$ What he means by this is that the person is free to do as he wishes, to act as his consciousness sees fit. In Sartre's form of existentialism the person lacks essence; there is no common human nature that unites all persons under the one banner of humanity. Instead, the person defines himself, "there is no determinism - man is free, man is freedom". ${ }^{25}$ There is no nature that must be obeyed, but in each and every action man is totally free to do whatever he desires.

Freedom to do whatever you wish is a liberating point of view. Yet, there is an element to Sartre's philosophy that tempers unrestrained freedom: anguish. The person indeed is free, but at the same time he recognizes that each person, as a for-itself, is free as well. "[W]hen I recognize, as entirely authentic, that man is a being whose existence precedes his essence, and that he is a free being who cannot, in any circumstances, but will his freedom, at the same time I realize that I cannot not will the freedom of others". ${ }^{26}$ Anguish occurs as freedoms collide; how can you maintain your own freedom while at the same time respecting and willing the freedom of the other? One example Sartre gives to explain anguish is a decision made during a time of war.

When... a military leader takes upon himself the responsibility for an attack and sends a number of men to their death, he chooses to do it and at bottom he alone chooses. No doubt he acts under a higher command, but its orders, which are more general, require interpretation by him and upon that interpretation depends the life of ten, fourteen or twenty men. ${ }^{27}$

Here is anguish. The general is free and his men are free, but that does not prevent him from making a decision that will likely cost the men their lives; it only causes him anguish.

When the freedom of the general and the freedom of his men collide, "the one emerges from the destruction of the other". ${ }^{28}$ Inevitably when two or more free beings come together, only one can survive. Freedom is maintained for yourself by the destruction of the freedom of the other, and in our example we clearly see that destruction. The crossing between two free for-themselves is

\footnotetext{
24 C. Macann, Four Phenomenological Philosophers, cit., p. 130.

25 D. Palmer, Sartre For Beginners, cit., p. 191.

26 J. P. Sartre, Existentialism and Humanism, cit., p. 203.

27 Ibidem, p. 190.

28 R. Cumming, The Philosophy of Jean-Paul Sartre, cit., p. 117.
} 
so intense that in his play, No Exit, Sartre wrote, "Hell is other people". ${ }^{29}$ The general must assert his will over the soldiers; the only alternative is to allow the soldiers to assert their will over him. If he allows that, he recognizes that he is no longer free to do his will, he is objectified by them. In order to avoid this, he must objectify them so that his freedom is maintained. The constant objectification is like hell. One "can have no access to the subjectivity of the Other, who appears to me as a simple object of consciousness". ${ }^{30}$ Without access to the for-itself of his soldiers, they remain mere objects for him.

When we come into contact with the other, because we have no way of knowing the freedom of the other, we make the person into an object for ourselves. Trying to maintain our freedom, we seek to get a handle on the freedom of the other. But their freedom, their for-itself (subjectivity), is revealed to us through their in-itself (objectivity). In the end we end up objectifying the body of the other as the result of trying to preserve our own freedom. Each person wills to maintain their own freedom, "[b]ut this is conceivable only if I assimilate the Other's freedom. Thus my project of recovering myself is fundamentally a project of absorbing the Other" ${ }^{31}$ We must realize that for Sartre, freedom is the foundation for any human dignity. The only way for you to maintain your freedom, and therefore dignity, is to absorb/assimilate/ appropriate the freedom of the other by treating them as an object rather than a subject.

John Paul II also places a high value on the freedom of the person, but offers a different perspective on "colliding freedoms". He starts from a common human nature, delineates freedom as a power of the will, and observes that the only way to live in true freedom is to make a gift of yourself to the other. For him, to be free is to love. "Love consists of a commitment which limits one's freedom - it is a giving of the self, and to give oneself means just that: to limit one's freedom on behalf of another" ${ }^{32}$ John Paul II insists on love, not use.

The fact that a person possesses a subjective quality in an objective world allows John Paul to differentiate the person from a mere object. The self-reflective subject has the ability to reason, and the freedom to follow that reason. "The value of the person is closely bound up with freedom, and

\footnotetext{
29 C. Macann, Four Phenomenological Philosophers, cit., p. 140.

Ibidem, p. 142.

R. Cumming, The Philosophy of Jean-Paul Sartre, cit., p. 210.

K. Wojtyła, Love and Responsibility, cit., p. 135.
} 
freedom is a property of the will" ${ }^{33}$ The freedom of the will allows a person to be his own master, to choose according to his reason, but freedom is not what defines the person for John Paul II. According to him, the only way to preserve your freedom and the value of the other person is through a free response to the other, and by free response he means love. By using your reason to restrain your own personal freedom and choose the good (freedom in this case) of the other, you maintain both your own freedom and the freedom of the other. "As long as we consider [love] only in the light of its subjective truth, we can obtain no full picture of it and can say nothing of its objective value. But this last is, after all, what matters most". ${ }^{34}$ His task is to show that the subjectivity of the person is in fact an objective reality. Objectively the person, who is a subject, has intrinsic value and is not merely an object.

"The experience of freedom goes hand in hand with the experience of truth". ${ }^{35}$ Freedom must correspond to truth otherwise it is not freedom, but a misuse of freedom. For example, you may pretend to be Frodo Baggins in The Lord of the Rings. However, if you interact with others as though you were on a secret quest to save Middle Earth, you are choosing to live in a world of fantasy. All your actions, though freely chosen, would not relate to the objective truth of reality and would be a misuse of your freedom. Jack may want his sexual fantasies to come true in his relationship with Wendy, but that does not mean that his sexual prowess should dominate her. Wendy may want Jack to want her, but her neediness does not excuse her to manipulate him. Their freedom must correspond to objective reality, not their whims.

"Freedom exists for the sake of love... freedom is the means and love is the end" ${ }^{36}$ This is directly contrary to Sartre's view of freedom. He asserts that freedom is the end, not love. In a sense, love would be foolish for Sartre, because love requires relegating one's freedom. "Sartre offers freedom from (not for) love". ${ }^{37}$ John Paul II, however, is adamant that we are free, not for the sake of liberality, but so that we can freely love. With freedom the person can give his love as he sees fit; he is not forced to love. By loving, the person can authentically pursue the good, in fact even the highest good. Love allows a person to be truly free. Love is the free rational choice to choose the freedom

\footnotetext{
$33 \quad$ Ibidem, p. 117.

34 Ibidem, p. 117-118.

35 Ibidem, p. 117.

36 Ibidem, p. 135-136.

37 D. Murphy, Review of Capstone Paper, Round 2, Email to the Author, 2007.
} 
of the other by limiting one's own freedom. Freedom in the human person is a means for the will to love.

The free will enables the human subject to act according to his self-reflective reason, which is in accord with human dignity. Further, freedom does not exist to dominate or be dominated; rather, it is a means to achieving the good for oneself and the good of all. Freedom is a means for authentic love. Through love one can maintain their own freedom while at the same time upholding the freedom of the other.

Reason is the distinctive element that makes a person a subject, and the freedom to follow this reason emphasizes the essential dignity of the human person. Since each person is free to rule their own lives according to reason, each person is an end in themselves. A person is not a good for another to use, as an object is a means for some other end, but good for their own sake. Let us take a second to recognize a key element of John Paul II's theory that dramatically separates him from Sartre. "Anyone who treats a person as the means to an end does violence to the very essence of the other, to what constitutes its natural right". ${ }^{38}$ In other words, to objectify the other (thus making them a means) is an offense against their dignity as a human subject. To do so is to treat a person as subhuman.

Love respects the dignity of the person by treating the other as an end and not a means. In connection with the dignity of the person, John Paul speaks of a personalistic norm. The personalistic norm states that "the person is the kind of good which does not admit of use and cannot be treated as an object of use and as such the means to an end... the person is a good towards which the only proper and adequate attitude is love". ${ }^{39}$ The response of love toward the other is the only way to respect their freedom and thus uphold the essential dignity of the other.

The personalistic norm is a rule of how the person ought to be treated, based on what the person is. It demands a response of love from one person to the other. Love is shown through the exercise of limiting one's own freedom as mentioned earlier, as well as making a gift of self to the other. The ideal example of the gift of self is through nuptial union of man and woman, a mutual self-giving for the sake of the other. ${ }^{40}$ Yet, in the interpersonal relationship we can recognize the elements of an unselfish, or "disinterested" gift of self that

\footnotetext{
$38 \quad$ K. Wojtyła, Love and Responsibility, cit., p. 27.

39 Ibidem, p. 41.

40 John Paul II, The Theology of the Body, cit., p. 63.
} 
seeks not for one's own good alone, but also the good of the other. The privation of the gift of self is to treat the other as an "object for myself". ${ }^{41}$ The gift of self then is not only a limiting of one's own freedom, but also seeking the good of the other for their own sake, it is self-sacrificing.

John Paul II is laying out the groundwork for the proper response to the objective truth about man. Sartre's viewpoint has no way of reconciling two persons as ends. For him, one must always choose either to make another a means for one's own end, or to become a means for the other. He illustrates that if one does not treat others as an end, they must treat them as a means. Although he does not believe in a common human nature, his analysis describes a human nature that lacks love, John Paul II's man of concupiscence. Sartre describes the person as a person for himself, always.

In Sartre's paradigm there is no way to preserve the dignity of the person when two or more people interact. Freedom must not be the end of persons because it does not match up with the objective reality that there are multiple persons with equal dignity. John Paul II calls the person who seeks their own will to the detriment of the dignity of the other the man of concupiscence. Sartre's paradigm describes the man of concupiscence as a person who has no love for the other, but rather only a love for the self. The person, for Sartre, cannot desire to see the good for the other because he must seek for his own good over and against the other - even if it is not the appropriate response to another person.

\subsection{Wendy and Jack...}

Returning to Jack and Wendy, we will see what role freedom plays in respecting the dignity of the other. Since they live together, they both benefit from the companionship of the other and from splitting the bills. There are definitely psychological, emotional, and personal needs that this relationship helps each of them to fulfill, and this is good. Although psychology can offer helpful insights into the situation, it is not the question at hand. What we are focusing on is the philosophical legitimacy of their actions. Without this objective revelation that we find through philosophy, psychology will remain entirely subjective with no grounding in reality. Are Jack and Wendy treating each other as persons, who are subjects, as they ought to be treated?

Objectively, it is not improper for a man and woman to live together. Neither is it wrong for a man and a woman to have intercourse with one another.

\footnotetext{
$41 \quad$ Ibidem, p. 70.
} 
It is not wrong to desire companionship, or see another person as attractive or beautiful. These are all goods. What Jack and Wendy must determine is whether they are treating the other as a means for their own enjoyment, or if they respond to each other as ends in themselves. If Wendy is staying with Jack chiefly because he provides her with emotional support and someone she can take with her to family/friend functions, she is using him as a means to her own end. If Jack enjoys Wendy because she will have intercourse with him and help keep the rent low, he is using her. They would be committing an abuse against the intrinsic worth of the other as a person. Such a violation of human dignity is a selfish using of the other as a person. Even if both Jack and Wendy were aware of each other's motives and freely consented to the situation it would not be objectively moral. Why? because they would be agreeing to a mutual use of one another regardless of the objective truth.

Even though they employ their rational powers and freely choose to submit themselves to being used by the other, the objective fact remains that they are subjects, persons that should never be used. According to Sartre, to use the other person for the sake of maintaining your freedom would be acceptable. However, that Jack should submit himself to being used by Wendy (or vice versa) would be a terrible offense of their subjective dignity, they would be giving up their freedom. This is what "the man of concupiscence" does-he uses the other. John Paul II insists that to use the other person is objectively wrong. Love, freely given to the other preserves the objective dignity of the other person. In this case, Jack and Wendy are not giving themselves to the other in a gift of love. They have only a mutual agreement to let the other use them. Letting another take from you is not love. Love requires giving yourself to the other in freedom.

Taking this one step further, when Jack and Wendy mutually take from one another, they only degrade the dignity of the other. In their attempt to love they use. But what if Jack and Wendy consent to a mutual agreement to give themselves to the other? This changes everything. They would still receive the secondary benefits of companionship, mutual support, combined efforts to pay bills, and the pleasure of sexual union, but they would primarily uphold the dignity of the other. Why not choose the way of love? Interestingly, this way of love lies in marriage. In canon 1057, the Code of Canon Law states that "[m]atrimonial consent is an act of the will by which a man and a woman mutually give and accept each other through an irrevocable covenant in order to establish marriage". What Jack and Wendy are really looking for is love in marriage. Marriage is a union based on the objective truth of the 
dignity of the person, not on subjective manipulation. The gift of self makes the difference between use and true love.

There is an old saying, "when the gods leave, the demi-gods come in". The man of concupiscence is a distortion of what man really is. Jack and Wendy may have never seen an example of a relationship where a man and woman live their lives together by living as a gift of self to the other. Jack does not want to feel like he is missing the boat all the time when it comes to the meaning of sex, and Wendy does not want to be used for what she can offer, but loved for who she is. Their relationship is better than what they have both seen and experienced before. Perhaps because their relationship is better than any they have seen before, they see it as very good. To their credit, they are doing better than others. However, just because they are doing better does not mean that they are doing the right thing. The hard part for them now is that their relationship is like the demi-god. Will they let their current situation prevent them from living the full truth of who they are as persons, or will they take steps toward loving one another through mutual self-giving?

\section{4. "The Look"}

There are some desires that are not desirable.

G. K. Chesterton in Orthodoxy

So far we have been talking about the "what" of the person, now we are going to look to "how" the person is treated. Both John Paul II and Jean-Paul Sartre talk about "the look," which works hand in hand with desire. The look is the mode in which the person upholds or appropriates the freedom and personhood of the other.

In Sartre's vision, the person is a subjective for-itself who is free. Through "the look" one appropriates the freedom of the other by making them into an object. He suggests that this appropriation of the other comes through the double aspect of "the look," the looker and the looked at. "In so far as I look at the Other, I affirm myself as an existing consciousness for which the Other is an object". ${ }^{42}$ Yet one cannot really obtain the other by objectifying them because one is only defining the other by their physicality (in-itself/objectivity), and there is more to a person than their objective physical appearance

\footnotetext{
42 C. Macann, Four Phenomenological Philosophers, cit., p. 142.
} 
(viz. the for-itself/subjectivity). In the attempt to apprehend the free for-itself, you take the other as simply an in-itself. If you wish not to objectify the other, the only other option is to become an object of the other's consciousness yourself. ${ }^{43}$ The result would be to lose your own freedom.

To use an example, imagine Jack asserts his freedom as a for-itself by acting on his desire for Wendy. In this situation, "Desire desires the desire of the Other" "44 Jack is intrigued by Wendy and wants her to want him. When he comes into the room where Wendy is, his desire manifests itself through the look. Jack knows that Wendy is a for-itself and he wants her to desire him. Wendy becomes aware that Jack is looking at her. "By the mere appearance of the Other, I am put in the position of passing judgment on myself as on an object, for it is as an object that I appear to the Other". ${ }^{45}$ She realizes that she is an object of his consciousness. This example illustrates the "double aspect" of the look for Sartre. The first aspect occurs when Jack looks at Wendy, sees her as an object of his desire and in that recognizes and expresses his own subjectivity, in that he is the "desire-er". The second aspect of the look becomes known as Wendy feels his look and recognizes that she is the object of his desire. Although Jack's desire is a desire to grasp her "free subjectivity", because she knows that she is an object for him, he fails to obtain it. ${ }^{46}$

He tries to appropriate her freedom as for-itself, by making her an object for himself. When Wendy becomes an object, a mere thing in-itself to Jack, her freedom is subjected to his. Her freedom is "lost" as he restricts her by making her an object. The opposite of what Jack wanted actually occurs. Despite his desire for her "free subjectivity", his look makes her a mere object of his consciousness. "I want the other to count as a transcendence by my attempt to utilize her as an object, and precisely because she is all object she escapes me with all her transcendence" ${ }^{47}$ In the look, Wendy loses the dignity and proper freedom due her as a person for-itself by being treated as an object in-itself. Horrifically, Sartre posits that treating the other as an object is a cycle that cannot be broken and has no other end than sadism. ${ }^{48}$ For Sartre, a person's free subjectivity is continuously compromised in the look of the other.

\footnotetext{
43 Ibidem.

44 D. Palmer, Sartre For Beginners, cit., p. 97.

45 R. Cumming, The Philosophy of Jean-Paul Sartre, cit., p. 189.

46 Ibidem, p. 210.

47 Ibidem, p. 223.

48 C. Macann, Four Phenomenological Philosophers, cit., p. 148.
} 
Sartre states that the fact that existentialism "defines man by his action" is the only theory compatible with the dignity of man, because "it is the only [theory] which does not make man into an object" ${ }^{49}$ Here Sartre redefines human dignity from inherent dignity as a person, to the dignity a person has because one defines himself as a free self. In Sartre's view, only if a person is free can they possess any dignity. Yet, if some action results in the loss of one's freedom, is one's dignity not forfeit as well? Indeed it is, for dignity is founded on the person as free. When man is the looker, he maintains his freedom. As the looked at, man becomes a mere object for another.

In John Paul II's writing, "the look" of Sartre is translated into the "lustful look." Nothing is wrong or abhorrent in the look itself, but if one is not careful to uphold the personalistic norm, "the look" becomes lustful- a means of objectifying the other. Let us make the distinction between the two "looks." The word that John Paul II refers to when speaking about the look is the Greek word $\beta \lambda \dot{\varepsilon} \pi \omega$. B $\lambda \dot{\varepsilon} \pi \omega$ literally means to see, observe, discern, perceive, implying a special contemplation. Interestingly, it also carries with it the connotation that expresses earnest contemplation. ${ }^{50}$ In this sense the look indicates a sense of wonder at the sight of what it perceives. When the look is used in proper relation to the dignity of the person it upholds the personalistic norm, seeing the other as an end to behold, even something to marvel at.

However, when this look is modified by a desire to objectify the other, then it sullies the purity of the look. The word that John Paul II draws from to indicate lust is $\dot{\varepsilon} \pi \imath \theta u \mu \varepsilon \dot{\varepsilon} \omega$. This means to set one's heart upon, to turn upon a thing, desire, long for, lust after, covet; it stresses the inward impulse indicating concupiscence. ${ }^{51}$ Concupiscence is the tendency to direct a natural inclination away from its proper aim, it is a disordered desire. Although $\dot{\varepsilon} \pi \imath v \mu \varepsilon \dot{c} \omega$ does not necessarily indicate an evil desire, it is rarely used to indicate a positive desire. Concupiscence expresses itself as "the lustful look" and obscures the significance of the body by neglecting personhood. ${ }^{52}$ The body of the other is in jeopardy of being looked upon as an object of lust because

\footnotetext{
49 J. P. Sartre, Existentialism and Humanism, cit., p. 198.

50 W. E. Vine, "Behold", [in:] Vine's Expository Dictionary of New Testament Words, McLean 1989, p. 116.

51 W. E. Vine, "Desire", [in:] Vine's Expository Dictionary of New Testament Words, McLean 1989, p. 299.

52 John Paul II, The Theology of the Body, cit., p. 149.
} 
of concupiscence. If there were no concupiscence, the look would be pure and the dignity of the body would be affirmed.

\subsection{Wendy and Jack...}

The look plays a shifting role in the lives of Jack and Wendy. As was mentioned earlier, when Jack looks lustfully at Wendy, he is seeing her as an object for him, he does not see her as she really is. For Wendy is a subject forherself, she is an end in herself. Looking through the lens of concupiscence, Jack will never be able to see Wendy as she really is. And this is precisely how Sartre describes how the look works. If Jack never sees Wendy as an end in herself, but always treats her as an object, he will gradually start treating her worse and worse until she is nothing but a means to pleasure for him. This is what Sartre meant by sadism. The same is true for Wendy. If she does not see Jack as an end in himself, but only as someone to share life with, to use for support, or to have someone to control, he will be nothing but an object of lust for her. The look that ends in lust is all bad because it disregards the essential dignity of the human person, who is a free subject. This is the man of concupiscence - the man for whom all others are objects. Lust has no other end than objectification.

For John Paul II a "look expresses what is in the heart". ${ }^{33}$ If the heart is pure, then the look will commit no offense against the personalistic norm but uphold the other as a subject and an end in themselves. If the look is tainted by inordinate desire it "indicates an experience of value to the body, in which its nuptial significance ceases to be that, just because of concupiscence". ${ }^{54}$ This "lustful look" makes the other into an object, reducing its rightful value. For the man who looks lustfully, "the woman ceases to exist as an object of eternal attraction. She begins to be only an object of carnal concupiscence".55 To him, she is no longer a subject different from other objects, with her own inherent dignity. Through the "lustful look," he sees her as an object, a means for attaining his own ends. The very same could be said of the woman who looks lustfully at the man.

The way out of the lustful look is through the disinterested gift of self. The disinterested gift of self treats the other as they truly are: a subject who is an end in themselves. "If man in his relationship with woman considers her

\footnotetext{
$53 \quad$ Ibidem, p. 147.

54 Ibidem.

55 Ibidem, p. 150.
} 
only as an object to gain possession of and not as a gift, he condemns himself thereby to become also for her only an object of appropriation, and not a gift". ${ }^{\text {" }}$ The "disinterested look" then sees the other as a gift, not something to be appropriated. With the "disinterested look" Jack can find the deeper meaning he has been looking for in the sexual encounter. If, instead of looking to Wendy as an object to gratify his sexual urges, he looks to her and offers the sincere gift of self, he would treat her as an end in herself-a subject, a for-itself. This would be a pure look.

If the look is pure, Jack would look to Wendy and see a wonder among creation. Her very body would reveal to him beauty as he never imagined. He would see a person who has fears, insecurities, hopes, and desires of her very own, different from all others. He would see the unique subjectivity of Wendy and be in awe that there could be another who is similar to him, another person. He would see the great dignity that she possesses as a person, and would seek to always uphold that dignity by respecting her as an end in herself, not something to be used but loved. To "look" like this is the process of climbing Mt. Everest and having that deeper appreciation. If Jack could see his face as he looked purely at Wendy he would see that his own face looked like those who climbed the mountain.

If the look is pure, Wendy could come home frustrated from a hectic day at work and make of herself a gift to Jack. She would not look at him and see someone to dump her frustrations on, not someone to manipulate to meet her demands. Rather, when she looked at him she would see strength and weakness. The more he offers himself as a gift to her, the more she will see such a strong will, a determined mind, a valiant and heroic spirit. And at the same time she will see such a fragile soul, a person who can be hurt precisely because he makes himself vulnerable as a gift to her. She too would see the dignity he has and seek to offer herself as a gift to him who is another subject just like her. She would not compromise with lust. For the pure look to exist there can be no lust, no treating the other as a mere means to some other end. The look without concupiscence may seem unattainable, perhaps unrealistic or even wishful thinking. In part, it is. Wendy and Jack live in a world of concupiscence, their desires are disordered and there are no glasses that can help straighten this vision. Their vision of one another needs to be re-ordered from its disordered state. They will need to work hard to find the truth about their desires, to recognize and "untwist" the lies that their concupiscence is based

$56 \quad$ Ibidem, p. 128. 
on. As they begin to treat one another more and more according to the truth of their dignity, they will be able to see more clearly. All this effort is needed, and ultimately they will also need their concupiscence to be redeemed so that their sight may be fully restored.

For both philosophers "the look" then becomes a means of objectifying the other. In Sartre, "the look" is an expression of desire to be desired, but ends in disappointment. The looker's desire is manifested in the other and they see themselves as an object. The looker then appropriates the other as only a thing in-itself. This description also applies to John Paul II's "lustful look." "The look" of possessing the other relegates the other to a mere means to be used rather than as an end in themselves. "The lustful look" is an attribute of the man of concupiscence, not of one upholding the personalistic norm. Freedom comes to be appropriated through "the look." The desirous look is perceived by the other, and for both Sartre and John Paul II, elicits a response of shame.

\section{Shame}

The first two facts which a healthy boy or girl feels about sex are these: first that it is beautiful and then that it is dangerous.

G. K. Chesterton in "Illustrated London News" 1/9/09

Shame can be the response of the one looked upon, or of the looker. When one realizes that they are not being treated in accord with the human dignity one intuitively knows they have, one experiences shame. Shame is neither good nor bad in itself, it is a response to "the look."

In one of his Wednesday audiences, John Paul II reflects that "this extorting of the gift from the other human being... and reducing him or her interiorly to a mere 'object for me', should mark the beginning of shame". ${ }^{57}$ This affirms what was said earlier about subjectivity, freedom, and "the look". You know, at least by proper reason if not intuitively, that because of your personhood you possess a dignity that elicits a response of certain behaviors and conduct. And when you realize that you are no longer being treated in accord with that dignity, you realize that you are being objectified; you are

$57 \quad$ Ibidem, p. 70. 
being treated as a thing, a means and not an end in yourself, and you experience the feeling of shame.

Before concupiscence entered the world "man and woman were not ashamed seeing and knowing each other in all the peace and tranquility of the interior gaze". ${ }^{58}$ The interior gaze is "the look" in its pure form, before it was tainted by objectifying lust. In this original state of innocence, as John Paul calls it, man and woman act and communicate according to the personalistic norm, becoming "a gift for each other". ${ }^{59}$ However, once man fails to act according to the real, objective truth of treating the other as an end in themselves through the free gift of self, the man of concupiscence takes over and lust enters the scene. The look becomes dirtied as it tends towards lust, and the other's gift of self is turned into "an object for me to have." The innocence that prevailed is now impossible to regain. That is why redemption is needed.

Understanding this break with innocence helps to explain how shame can be a good. "Man is ashamed of his body because of lust. In fact, he is ashamed not so much of his body as precisely of lust". ${ }^{60}$ This shows that shame acts as an affirmation of the goodness of the body and at the same time is an attempt to safeguard the value of person in the face of lust. In a way, shame helps preserve the personalistic norm. Shame is an affirmation of the body because one does not feel shame of their body until they feel a value being placed on their body. ${ }^{61}$ It is not the body which is bad, but an evaluating of the body through objectification. Shame does not enter the picture because of one's body, but at the point when one's body is seen as "a potential object for enjoyment". ${ }^{62}$ Affirming the inherent value of the person through the body leads shame to act as a safeguard against objectification (which again affirms the true value of the person in their body). When, through the lustful look one is made into an object of enjoyment, shame is a realization of an undervaluing of the intrinsic worth of a person. So we can say that shame "indicates the threat to the value and at the same time preserves this value interiorly". ${ }^{63}$ This twofold aspect of shame emphasizes the underlying dignity that comes with personhood.

\footnotetext{
$58 \quad$ Ibidem, p. 58.

59 Ibidem.

$60 \quad$ Ibidem, p. 116.

$61 \quad$ K. Wojtyła, Love and Responsibility, cit., p. 176.

62 Ibidem.

63 John Paul II, The Theology of the Body, cit., p. 117.
} 
"It can even be said that man and woman, through shame, almost remain in the state of original innocence... preserving [the body] from lust". 64 Shame points one in the direction of the proper response to the other, which is love. Love, as expressed through the limiting of one's own freedom in the disinterested gift of self, is the mode of the personalistic norm and allows for the possibility of a true communion of persons. Rather than justifying the use of persons, shame can lead to treating the other person as an end in themselves.

Now, shame can be underdeveloped, and this leads to a misunderstanding of one's own body and the dignity of the person. An underdeveloped sense of shame is when a person sees no reason to exercise a "sexual modesty" and reveals their body in a way that obscures their value as a person. ${ }^{65}$ "The consequence is that the person is put in the position of an object of use, a being which can be treated as something merely to be used... not to be loved". ${ }^{66}$ Instead of accepting and acting according to their own dignity as a personal subject, the person sees himself as an object. An underdeveloped sense of shame leads to immodesty, which is aimed at arousing concupiscence and displaying the body as an object for enjoyment. ${ }^{67}$ Even though the person may claim that they can do whatever they wish with their own body, they cannot separate from the objective truth of the value of their person. "We cannot consider the body an objective reality outside the personal subjectivity of man". ${ }^{68}$ The body remains always a part of the person as a subject; in presenting the body immodestly, the person degrades their own dignity.

John Paul II posits that the proper understanding of shame acts as a sort of limit. In a way shame marks out the boundary which separates proper response to the person from an inappropriate or degrading response. When the limit of shame is overstepped, the "governing rules of the gift and mutual donation" are violated and abuses such as pornography take place. ${ }^{69}$ When the possibility of gift is taken away, appropriation occurs and the dignity of the person is violated. The shameless person does not properly understand why the boundary of shame exists.

\footnotetext{
${ }^{64}$ Ibidem, p. 122.

${ }^{65}$ K. Wojtyła, Love and Responsibility, cit., p. 187.

66 Ibidem, p. 188.

67 Ibidem, p. 190.

68 John Paul II, The Theology of the Body, cit., p. 218.

69 Ibidem, p. 223.
} 
On the other side of the coin, an overdeveloped sense of shame can be problematic as well. In this case a person sees the body itself as shameful. An overdeveloped sense of shame is also a misunderstanding of shame because the person believes that everything to do with the body leads to objectification and use, that the body is bad. Those in this camp do not see how the body is a part of the personalistic norm. They have failed to understand that it is the devaluing of the body that is shameful, not the body itself. The body is, objectively, an integral part of the person and this must be taken into account to develop a proper understanding of shame.

Jean-Paul Sartre also speaks about shame as a result of "the look." When we recognize ourselves as objectified we experience shame and we come to the crux of subjective freedom. "Shame is therefore the experience of my own subjectivity being wrenched away from me, appropriated, even expropriated by the other - for whom I am nothing but an object". ${ }^{70}$ Through the look we appropriate another as an object. The other then feels shame as their own freedom, their own dignity is wrenched away.

Sartre makes several statements about what shame is. "Pure shame is not a feeling of being this or that guilty object but in general of being an object; that is, of recognizing myself in this degraded, fixed, and dependent being which I am for the Other". ${ }^{\prime 1}$ In this sense, shame occurs not because you did something wrong, but because you are something wrong. You become just another thing among things, rather than a free individual.

Shame is closely connected with the look. Sartre writes that "the Other's look embraces all my being." ${ }^{72}$ The person as free has the possibility to be or do anything. But in the moment of the look,

I perceive that these possibilities which I am and which are the condition of my transcendence are given also to another, given as about to be transcended in turn by his own possibilities. The Other as a look is only that - my transcendence transcended...

Thus in the jolt I feel when I apprehend the Other's look, suddenly I experience a subtle alienation of all my possibilities...I am no longer the master of the situation. $^{73}$

\footnotetext{
70 C. Macann, Four Phenomenological Philosophers, cit., p. 143.

71 R. Cumming, The Philosophy of Jean-Paul Sartre, cit., p. 205.

72 Ibidem, p. 199.

73 Ibidem, p. 201, 203.
} 
The objectified person is a person whose own for-itself has been transcended by the other. As a mere object the person is no longer free, no longer able to be who he is, and that causes shame. Donald Palmer sums up Sartre's explanation of shame, freedom and the look:

I discover myself in shame. I am responsible for the self which has been revealed to me by the Other's gaze, but this self's grounding is outside me. In the moment of shame my freedom escapes me and the Other's freedom is revealed to me. I am forced to recognize myself not in my aspect of being-for-itself but in my aspect of being-in-itself. ${ }^{74}$

Shame for Sartre can be described as the for-itself/subjective being verboten, the person to be seen as only the in-itself in "the look" of the other. There is not a positive aspect of shame here, but only the negative aspect of having one's freedom denigrated.

Sartre's statement which maintains that existentialism is the only theory that does not objectify man (see above) can indeed be true. However, it can be true only in the sense that a man can remain a subject only by objectifying the other, all others. Here lies a vicious cycle. This process of objectification can never lead to the enjoyment of an other as a for-itself, affirming their dignity, but will always wrench away the freedom, and thus the dignity, of the other "by a degeneration" to the other. ${ }^{75}$ In order to avoid the shame of one's own objectification, one must objectify the other.

Shame for Sartre is the realization that you are an object in the eyes of the other. John Paul II agrees that there is shame when one is treated as an object, but has a more developed idea of what shame actually is. Shame has a negative connotation for Sartre, whereas John Paul II sees shame as a neutral quality. It is a response to the "lustful look," but has the positive attributes of safeguarding the value of the person as a subject and affirming the value of the body. Shame acts as a boundary for how the person ought to be treated. It is the line of treating the person as a subject or an object.

\section{Wendy and Jack...}

Shame can be seen in Jack and Wendy's relationship. Jack is not proud of the times he has looked at pornography. Why? Even though the images he sees are inanimate pictures he is still committing an act of lust. He is looking

44 D. Palmer, Sartre For Beginners, cit., p. 94.

75 C. Macann, Four Phenomenological Philosophers, cit., p. 146. 
at a picture of a woman, who is her own subjective for-itself. He makes the female person an object of his own lust, to be used for his pleasure rather than treating the image of the person with the honor a person deserves. He takes away the possibility of mutual self gift. The image cannot reciprocate a gift to Jack, nor can he give himself to mere image. Now the image feels no shame, so Sartre's stance on shame cannot be applied to Jack. Yet, John Paul II's analysis offers some light. Jack feels shame because he innately knows he is violating the true meaning of the body - to reveal the subjective for-itself of the other, the dignity or value of the other. When the dignity due to the body is taken away, the limit of shame is overstepped, and Jack feels shame because he disregards the dignity of the other and ultimately he is unsatisfied. This process of objectification will carry over into his personal relationship with Wendy and other women; it becomes increasingly difficult not to treat them as objects. In a sense, Jack is a victim of his own abuse.

Wendy too feels shame. One day Wendy decided to go swimming at the gym. After she finished her laps, she took a shower in the locker room and began to get dressed. As she was getting dressed she looked up and saw two teenage boys with their jaws dropped just staring at her. Somehow they had entered the wrong locker room. She screamed and covered herself with her towel and they ran away. Here we can see several aspects of shame. According to Sartre's view, she experiences shame because she realizes that they are looking at her as an object and not a person. She is a thing for them to behold and she realizes that as she is held by their look. John Paul II would agree with Sartre, as the one objectified she feels shame. But this incident also points out the positive aspect of shame. By screaming and covering herself, an instinctual reaction, Wendy is affirming the value of her body. She affirms her dignity by refusing to be treated as an object. Although she experiences the shame more than those two teenagers would, it is not any fault of her own. She bears the shame as an object of someone else's lust, but it affirms the value of her dignity as a person.

It is also possible for both Jack and Wendy to experience shame when they join in sexual union together. This is easy to explain for Sartre. As the one being objectified or used in the sexual encounter, Jack or Wendy experience the shame of being looked upon as less than they really are. Their dignity is compromised. As the one who objectifies the other, you are gratified; your freedom remains intact. In the sexual encounter both cannot avoid shame. For John Paul II, it is different. The gift of self must be free, and if it is to be "gift" at all it must be total not conditional. 
Jack and Wendy will experience shame when the possibility of the gift of self is taken away. If Wendy cannot give herself freely to Jack, but he instead takes from her what he desires, the limit of shame is crossed; the dignity of the other is violated. It is possible for Wendy to make a gift of herself to Jack. If she freely chooses to give herself to him, and offers herself to him in a gift of love through the sexual union, their intimate sharing can be without shame. Jack could look at the naked body of Wendy and recognize the gift she offers to him in giving her very self. His proper response would be to make of himself a gift of love to her. Offering her his very body freely as a sign of his love for her not only honors the gift she offers to him, but also preserves the dignity of both persons. However, the moment Jack seeks to "take" Wendy as an object for himself, shame enters in and a free and total union is taken away. In the same way, if Wendy should "take" away Jack's gift of self to her and make him a "thing" for her, his personhood is compromised. John Paul II points Jack and Wendy to truly treat each other as persons, respecting the dignity of the other. Jean-Paul Sartre's scenario describes the person who chooses their own desires over and above the objective truth of a real existing person. The dignity of the person demands that a person be treated in a certain way. When human dignity is disregarded, the man of concupiscence reigns, and it is not how it should be.

This paper discusses four common aspects of the philosophies of JeanPaul Sartre and John Paul II. The reader should be fully aware that both men wrote extensively and have a large corpus of writings in which they discuss, refine, and add to their thoughts and explanations. For our part we have examined the difference between objectivity and subjectivity, noting the nuance between the philosophers as to what constitutes the vital element of the person as a subject. We have seen that for Sartre, freedom is the essential element of human dignity; whereas for John Paul II freedom is a means for the end of the rational person to give authentic love to another. When two persons come into contact we learned that "the look" is a means for objectifying the other as means for one's own end. Sartre posits that "the look" must end in the appropriation of the other. John Paul II argues that when sullied by lust the look becomes a means of denigrating the dignity of the other. But the look can be good, as a beholding of the integral truth of the other as a person/subject. Finally, as we discussed shame, we saw that what is only a negative quality for Sartre, is a neutral quality for John Paul II that has positive aspects, even though it is the result of a negative act.

In sum we can say that Jean-Paul Sartre describes John Paul II's man of concupiscence. As he aims to know what the person truly is and how he ought 
to be treated, John Paul II not only describes what the proper dignity of the person is, but also the proper response to the person based on the objective truth of personhood. Jean-Paul Sartre's explanations describe this failing man. He takes his observations of what he sees in everyday life and tries to explain what system people must use in order to treat one another the way they do. John Paul II is trying to point us toward who man was always supposed to be. It is now our task to overcome, as much as possible, the faulty understanding of the person in society, and to both act and treat others according to the objective truth of the dignity of the person.

The mutualistic relationship between Jack and Wendy provides one example of an interpersonal relationship. Their relationship does not have to be based on concupiscence. Jack and Wendy can truly treat the other person as a person if they always respect the dignity of the other. When Jack recognizes Wendy for who she is as a person, all his actions will be in accord with her personhood. Through the use of his freedom, he can choose not to compromise her dignity by treating her as an object. Rather, he will always seek to treat her as a subject, as a person who was not made to be used but loved. His look will not seek to appropriate her as an object for his lust, but he will stare at her with wonder and awe, contemplating the presence of another; another person like himself. Inevitably he will fail, but the limit of shame will remind him of what ought not be done, and he can once again orient himself and make a gift of himself to her, rather than taking her as an object for himself.

Yet, redemption is still needed. "Redemption signifies, as it were, a 'new creation'". ${ }^{76}$ Redemption is the non-existence of all the problems that come with "the man of concupiscence." The redemption of the body is the removal of the demi-god of concupiscence through the union with the Perfect, the Original, the Innocent. This perfect union is most concretely manifested to humanity in the sacrament of marriage, because marriage links us to what always was from the beginning. "Redemption becomes at the same time the basis for understanding the particular dignity of the human body, rooted in the personal dignity of the man and the woman" ${ }^{77}$ Redemption allows us to truly live and act according to the dignity of the other rather than in accord with our tainted desires.

Human beings are more than mere objects, and this fact has obligations for how we ought to treat one another. The principles of objectivity/

\footnotetext{
76 John Paul II, The Theology of the Body, cit., p. 344.

77 Ibidem, p. 345.
} 
subjectivity, freedom, "the look," and shame, can and ought to be applied to the mutualistic relationship as well as to other issues that regard the dignity of the person. Issues such as substandard working conditions, pedophilia, incest, homosexual marriage, subliminal manipulation, emotional abuse, and physical abuse are all dependant on the dignity of the person. We can choose to follow our own desires, ignoring objective reality and act as people of concupiscence, or we can treat each other as persons and act in accord with the dignity we all possess. 